5. Лепа Р.Н. Ситуационный механизм подготовки и принятия решений на предприятии: методология, модели и методы/ Лепа Р.Н. - Донецк: ООО «ЮгоВосток ЛТД», 2006. - С. 233-257.

6. Таран Т.А. Отображение принципов рефлексивного управления в математических моделях рефлексивного выбора / Т.А. Таран // Рефлексивные процессы и управление. - М.: Институт психологии РАН, 2002. - Т. 2. - № 1. - С. 104-117.

7. Петрачкова Е.Л. Рефлексивное управление механизмами формирования спроса на продукцию промышленных предприятий / Е.Л. Петрачкова // Экономика промышленности. - 2006. - №4. - С. 165-172.

8. Крамер 3. Х. От предсказаний к рефлексивному управлению / 3. Х. Крамер, Т. Б. Кайзер, С. Е. Шмидт, Дж.Е. Дависон, В.А. Лефевр // Рефлексивные процессы и управление. - М.: Институт психологии РАН, 2003. - Т. 3. - № 2. - С. 35 56.

9. Сорос Дж. Алхимия финансов / Дж. Сорос / - М.: Инфра-М, 2001. - 416 с.

10. Буєвич С.Ю. аналіз фінансових результатів банківської діяльності [текст] : навч. посібник / С.Ю. Буєвич / - М.: КНОРУС, 20055. - 160 с.

11. Герасимчук 3.В. Екологічна безпека регіону: діагностика та механізм забезпечення / 3.В. Герасимчук, А.О. Олексюк. - Луцьк: Надстир'я, 2007. - 280с.

12. Герасимчук 3.В. теоретичні та прикладні засади прогнозування стійкого розвитку регіону: монографія / 3.В. Герасимчук, І.С. Кондіус / - Луцьк: Надстир'я, 2010. - 412 с.

*УДК 338.434

Корецька Н.І., к.е.н., доцент

Олійник С.Б.

Луцький національний технічний університет

\title{
ОЦІНКА ФІНАНСОВОЇ ПІДТРИМКИ РОЗВИТКУ СІЛЬСЬКОГО ГОСПОДАРСТВА В РЕГІОНАХ УКРАЇНИ
}

Досліджено особливості фінансової підтримки сільського господарства у період 2015-2017 років. Встановлено, що обсяги державного фінансування розподілялися між регіонами пропорційно обсягам продукції, виробленої сільськогосподарськими підприємствами, що здійснюють діяльність на їх території. Проаналізовано стан банківського кредитування сільського господарства та визначено, що довіра сільськогосподарських підприємств до банків поступово відновлюється, однак банки продовжують вважати кредитування даного виду економічної діяльності високо ризиковим.

* Корецька Н.І., Олійник С.Б. 
Визначено пріоритети подальшої фінансової підтримки сільського господарства регіонів України.

Ключові слова: сільське господарство, сільськогосподарські підприємства, фінансова підтримка, кредитні ресурси, регіон.

\section{Koretskya N., Oliynyk S. \\ ASSESSMENT OF FINANCIAL SUPPORT DEVELOPMENT OF AGRICULTURE IN THE REGIONS OF UKRAINE}

Since agriculture is one of the most important types of economic activity, due to its specific features, it needs some financial support, which will accelerate the growth of agricultural production and increase the competitiveness of this type of economic activity.

It was investigated that as of January 1, 2015, there were 45,400 agricultural enterprises in the country, of which 32,2 thousand were farms; as of January 1, $2016-47.7$ thousand agricultural enterprises, of which 33.7 thousand - farms; as of January 1, 2017 - 45.6 thousand agricultural enterprises, of which 34.1 thousand - farms.

In the period of 2015-2017, financial support was provided: measures by reducing the cost of loans; development of farms (carried out through the Ukrainian state fund of support of farms); livestock breeding; agricultural producers.

The volume of state financial support provided to agriculture was analyzed, and it was established that in the years 2015-2017 it was financed by UAH 540.6 million; 330.8 million UAH and UAH 499.1 million. in accordance. It should be noted that in 2017, compared with 2016 , state financing by reducing the cost of loans decreased by $16.0 \%$, but increased in support of the development of farms $(8.2 \%)$ and livestock (17.8\%).

The analysis of state financial support in general in the regions of Ukraine shows that in 2015 the largest volumes of funding were received from Poltava and Chernihiv regions, in 2016 - Vinnytsia and Kyiv regions, and in 2017 - Vinnytsya, Odesa, Poltava, Dnipropetrovsk and Cherkasy regions. In our opinion, this situation is explained by the activity in these regions of a significant number of agricultural enterprises, including farms, and significant volumes of their production of agricultural products.

Regarding the insignificant state financial support, this situation was typical for Transcarpathian (2015-2017 years). It should be noted that the lowest gross agricultural output was characteristic of the Transcarpathian region. We believe that this situation is primarily due to the natural conditions in Transcarpathia, which does not allow for a sufficient level of profitability of agriculture.

In addition, state financing, the main source of financial resources for the ongoing activities of agricultural enterprises, remains bank lending.

According to the statistics of the National Bank of Ukraine, it should be noted that the volume of credit resources provided by deposit-taking corporations (except for the NBU) to agricultural enterprises for the period 2015-2017, grew from UAH 48425 million. to 59706 million UAH, that is $23.3 \%$.

Total regions of Ukraine attracted credit funds worth 48.4 billion UAH. in 2015; for the amount of 55.4 billion UAH. in 2016; to the amount of 59.7 billion UAH. in 2017 Thus, 
for the analyzed period, the volume of attraction of credits to agriculture increased by $23.3 \%$, which indicates the restoration of trust between banks and the agrarian sector.

In the period of 2015-2017, the largest volumes of credit resources in Ukraine were attracted by the agricultural enterprises of the Kyiv region, and the smallest - Lugansk (2015), Transcarpathian (2015-2016) and Donetsk (2017) regions.

In order to formulate strategies for financing further development of agriculture in the regions of Ukraine, we consider it necessary to group regions according to the level of financial support of agriculture.

After analyzing the regions by level of financing, it was established that some regions, ahead of other regions in terms of agricultural production, did not maintain the necessary funding.

Based on this, the priorities of further financial support of agriculture in the regions of Ukraine are determined.

Key words: silske gospodarstvo, silskogospospodarski pidpriєestva. fnansova pidtrimka, credit resources, region.

Корецкая Н. И., Олийнык С. Б.

\section{ОЦЕНКА ФИНАНСОВОЙ ПОДДЕРЖКИ РАЗВИТИЯ СЕЛЬСКОГО ХОЗЯЙСТВА В РЕГИОНАХ УКРАИНЫ}

Исследованы особенности финансовой поддержки сельского хозяйства в период 2015-2017 годов. Установлено, объемы государственного финансирования распределялись между регионами пропорционально объемам продукции, производимой сельскохозяйственными предприятиями, осуществляющими деятельность на их территории. Проанализировано состояние банковского кредитования сельского хозяйства и определено, что доверие предприятий к банкам постепенно восстанавливается, однако банки продолжают считать кредитование данного вида экономической деятельности высоко рисковым. Определены приоритеты дальнейшей финансовой поддержки сельского хазяйства регионов Украины.

Ключевые слова: сельское хозяйство, сельскохозяйственные предприятия, финансовая поддержка, кредитные ресурсы, регион.

Постанова проблеми у загальному вигляді та ії зв'язок 3 важливими науковими і практичними завданнями. Види економічної діяльності $\epsilon$ основою забезпечення сталого соціальноекономічного розвитку країни в цілому та їі регіонів зокрема. Саме на рівні регіону здійснюється початкове акумулювання та розподіл усіх ресурсів, в тому числі і фінансово-кредитних. Отже, розвиток національної економіки неможливий без врахування регіональних особливостей, що характеризуються наявністю певних ресурсів та визначенням потреби в додаткових ресурсах. А оскільки сільське господарство 
$€$ одним із найбільш важливих видів економічної діяльності, то в силу своїх специфічних особливостей потребує певної фінансової підтримки, що дозволить прискорити темпи зростання обсягів сільськогосподарського виробництва і підвищити конкурентоспроможність даного виду економічної діяльності. Тому дана проблема є актуальною.

Аналіз останніх досліджень, у яких започатковано вирішення проблеми. Проблему фінансової підтримки сільського господарства досліджували: В. Андрійчук, В. Бойко, Б. Кваснюк, Ю. Лузан, В. Месель-Веселяк, О. Могильний, А. Стельмащук, П. Саблук, Г. Черковський та інші, а проблему кредитного забезпечення даної галузі економіки - М. Дем'яненко, П. Стецюк, О. Гудзь, О. Непочатенко та інші. Разом $з$ тим, недостатньо вивченою залишається проблема ефективного розподілу коштів фінансової підтримки сільського господарства в розрізі регіонів, що потребує подальшого наукового розгляду.

Цілі статті: оцінка регіональних особливостей фінансової підтримки сільського господарства у період 2015-2017 років та визначення пріоритетності регіонів щодо подальшого додаткового фінансування.

Викладення основного матеріалу дослідження 3 повним обгрунтуванням отриманих наукових результатів. Сільське господарство в Україні є важливим сектором економіки країни, частка якого становить $21 \%$ загального обсягу валової доданої вартості (розраховано за даними джерела: [1]). I, не дивлячись на те, що сільське господарство в останні роки за темпами і стабільністю зростання інвестицій залишається лідером серед усіх галузей в Україні (у 2017 році приріст вкладень в дану галузь склав 58\% (розраховано за даними джерела: [1])), необхідно продовжувати пошук додаткових джерел фінансування.

Дані Держкомстату України свідчать, що станом на 1 січня 2015 року в країні функціонувало 45,4 тис. сільськогосподарських підприємств, 3 яких 32,2 тис - фермерські господарства; станом на 1 січня 2016 року - 47,7 тис. сільськогосподарських підприємств, з яких 33,7 тис - фермерські господарства; станом на 1 січня 2017 року - 45,6 тис. сільськогосподарських підприємств, 3 яких 34,1 тис - фермерські господарства.

Значна частина господарств в Україні - це малі та середні підприємства, які не мають можливості залучити достатні фінансові ресу- 
рси для забезпечення ефективного господарювання, підвищення його результативності. Це, в свою чергу, вимагає використання механізмів різновекторної підтримки.

Щороку в Законі «Про державний бюджет України» визначаються види державних цільових програм на підтримку сільського господарства і суми витрат на них, формуються урядові програми на відповідний рік.

Зупинимося на основних урядових програмах, відповідно до яких надавалася державна підтримка сільського господарства у період 2015-2017 років. Так, здійснювалася фінансова підтримка:

- заходів шляхом здешевлення кредитів;

- розвитку фермерських господарств (здійснюється через Український державний фонд підтримки фермерських господарств);

- тваринництва;

- сільгосптоваровиробників.

Проаналізуємо обсяги державної фінансової підтримки, що надавалися в сільське господарство у період 2015-2017 років (табл. $1-3)$.

Таблиця 1

Рейтинг регіонів за обсягами державної фінансової підтримки сільського господарства у 2015 році, тис. грн.

\begin{tabular}{|c|c|c|c|c|c|}
\hline Регіони & Всього & $\begin{array}{c}\text { Фінансова } \\
\text { підтримка } \\
\text { заходів шляхом } \\
\text { здешевлення } \\
\text { кредитів }\end{array}$ & $\begin{array}{c}\text { Фінансова } \\
\text { підтримка } \\
\text { розвитку } \\
\text { фермерських } \\
\text { господарств }\end{array}$ & $\begin{array}{c}\text { Фінансова } \\
\text { підтримка } \\
\text { тваринництва }\end{array}$ & $\underset{0}{E}$ \\
\hline 1 & 2 & 3 & 4 & 5 & 6 \\
\hline Вінницька & 38997,0 & 33695,0 & 1792,0 & 3510,0 & 5 \\
\hline Волинська & 30023,2 & 16763,0 & 394,2 & 12866,0 & 8 \\
\hline Дніпропетровська & 17751,5 & 11199,0 & 2260,5 & 4292,0 & 12 \\
\hline Донецька & 17388,2 & 406,0 & 988,2 & 15994,0 & 15 \\
\hline Житомирська & 9119,0 & 5514,0 & 407,0 & 3198,0 & 21 \\
\hline Закарпатська & 1490,3 & 993,0 & 120,3 & 377,0 & 24 \\
\hline Запорізька & 15702,6 & 12446,0 & 1328,6 & 1928,0 & 16 \\
\hline Івано-Франківська & 11636,3 & 5088,0 & 225,3 & 6323,0 & 18 \\
\hline Київська & 29087,5 & 18974,0 & 1131,5 & 8982,0 & 9 \\
\hline Кіровоградська & 17561,8 & 9717,0 & 2531,8 & 5313,0 & 13 \\
\hline Луганська & 3392,7 & 1396,0 & 1287,7 & 709,0 & 23 \\
\hline Львівська & 19157,8 & 15339,0 & 908,8 & 2910,0 & 11 \\
\hline
\end{tabular}


Економічні науки". - Серія "Облік і фінанси". - Випуск 15 (57). - 2018.

Продовження табл. 1

\begin{tabular}{|c|c|c|c|c|c|}
\hline 1 & 2 & 3 & 4 & 5 & 6 \\
\hline Миколаївська & 9404,6 & 7877,0 & 1520,6 & 7,0 & 19 \\
\hline Одеська & 10768,1 & 8383,0 & 1838,1 & 547,0 & 17 \\
\hline Полтавська & 55896,0 & 23512,0 & 1559,0 & 30825,0 & 1 \\
\hline Рівненська & 6172,5 & 5919,0 & 253,5 & 0,0 & 22 \\
\hline Сумська & 36552,0 & 9110,0 & 704,0 & 26738,0 & 6 \\
\hline Тернопільська & 31835,8 & 10657,0 & 629,8 & 20549,0 & 7 \\
\hline Харківська & 39084,1 & 22090,0 & 1454,1 & 15540,0 & 4 \\
\hline Херсонська & 17528,7 & 10549,0 & 1246,7 & 5733,0 & 14 \\
\hline Хмельницька & 26098,5 & 24982,0 & 1003,5 & 113,0 & 10 \\
\hline Черкаська & 39987,7 & 27295,0 & 1159,7 & 11533,0 & 3 \\
\hline Чернівецька & 9595,0 & 5993,0 & 233,0 & 3369,0 & 20 \\
\hline Чернігівська & 46369,1 & 12103,0 & 622,1 & 33644,0 & 2 \\
\hline Україна & 540600,0 & 300000,0 & 25600,0 & 215000,0 & \\
\hline
\end{tabular}

Примітка. Сформовано на основі даних джерел: [2-4]

Дані наведено без урахування тимчасово окупованої теритоpiї АР Крим, м. Севастополя

Таблиця 2

Рейтинг регіонів за обсягами державної фінансової підтримки сільського господарства у 2016 році, тис. грн.

\begin{tabular}{|c|c|c|c|c|c|}
\hline Регіони & Всього & $\begin{array}{c}\text { Фінансова } \\
\text { підтримка } \\
\text { заходів шляхом } \\
\text { здешевлення } \\
\text { кредитів }\end{array}$ & $\begin{array}{c}\text { Фінансова } \\
\text { підтримка } \\
\text { розвитку } \\
\text { фермерських } \\
\text { господарств }\end{array}$ & $\begin{array}{c}\text { Фінансова } \\
\text { підтримка } \\
\text { тваринництва }\end{array}$ & 志 \\
\hline 1 & 2 & 3 & 4 & 5 & 6 \\
\hline Вінницька & 34314,6 & 32930,2 & 1159,6 & 224,8 & 1 \\
\hline Волинська & 9388,8 & 8063,7 & 265,8 & 1059,3 & 16 \\
\hline Дніпропетровська & 13098,7 & 11187,3 & 1301,9 & 609,5 & 12 \\
\hline Донецька & 741,8 & 183,4 & 558,4 & 0,0 & 23 \\
\hline Житомирська & 12252,5 & 6607,1 & 261,0 & 5384,4 & 14 \\
\hline Закарпатська & 263,7 & 46,4 & 74,4 & 142,9 & 24 \\
\hline Запорізька & 13719,9 & 12965,3 & 754,6 & 0,0 & 10 \\
\hline Івано-Франківська & 6048,8 & 4622,6 & 148,7 & 1277,5 & 21 \\
\hline Київська & 32971,2 & 30079,0 & 721,4 & 2170,8 & 2 \\
\hline Кіровоградська & 13197,7 & 10427,7 & 1567,7 & 1202,3 & 11 \\
\hline Луганська & 4104,0 & 3360,5 & 743,5 & 0,0 & 22 \\
\hline Львівська & 9229,1 & 8470,8 & 539,4 & 218,9 & 18 \\
\hline Миколаївська & 8834,2 & 7924,6 & 909,6 & 0,0 & 19 \\
\hline
\end{tabular}


Економічні науки". - Серія "Облік і фінанси". - Випуск 15 (57). - 2018.

Продовження табл. 2

\begin{tabular}{|c|c|c|c|c|c|}
\hline 1 & 2 & 3 & 4 & 5 & 6 \\
\hline Одеська & 12326,3 & 10983,3 & 1240,2 & 102,8 & 13 \\
\hline Полтавська & 19043,8 & 17735,8 & 908,0 & 400,0 & 7 \\
\hline Рівненська & 17506,0 & 7921,0 & 164,5 & 9420,5 & 8 \\
\hline Сумська & 9244,8 & 6448,6 & 477,7 & 2318,5 & 17 \\
\hline Тернопільська & 21439,5 & 18226,4 & 398,6 & 2814,5 & 3 \\
\hline Харківська & 19286,0 & 18336,8 & 949,2 & 0,0 & 6 \\
\hline Херсонська & 7576,6 & 6863,1 & 708,7 & 4,8 & 20 \\
\hline Хмельницька & 21247,7 & 19606,8 & 673,9 & 967,0 & 4 \\
\hline Черкаська & 20319,4 & 19068,5 & 716,6 & 534,3 & 5 \\
\hline Чернівецька & 9783,4 & 9628,4 & 155,0 & 0,0 & 15 \\
\hline Чернігівська & 14880,6 & 13312,6 & 420,8 & 1147,2 & 9 \\
\hline Україна & 330819,1 & 284999,9 & 15819,2 & 30000,0 & \\
\hline
\end{tabular}

Примітка. Сформовано на основі даних джерел: [5-7]

Дані наведено без урахування тимчасово окупованої теритоpiї АР Крим, м. Севастополя.

Таблиця 3

Рейтинг регіонів за обсягами державної фінансової підтримки сільського господарства у 2017 році, тис. грн.

\begin{tabular}{|c|c|c|c|c|c|}
\hline Регіони & Всього & $\begin{array}{c}\text { Фінансова } \\
\text { підтримка } \\
\text { заходів шляхом } \\
\text { здешевлення } \\
\text { кредитів }\end{array}$ & $\begin{array}{c}\text { Фінансова } \\
\text { підтримка } \\
\text { розвитку } \\
\text { фермерських } \\
\text { господарств }\end{array}$ & $\begin{array}{c}\text { Фінансова } \\
\text { підтримка } \\
\text { сільгосп- } \\
\text { товаро- } \\
\text { виробників }\end{array}$ & 志 \\
\hline 1 & 2 & 3 & 4 & 5 & 6 \\
\hline Вінницька & 36608,7 & 25118,0 & 4550,0 & 6940,7 & 1 \\
\hline Волинська & 7440,4 & 5044,0 & 1040,0 & 1356,4 & 20 \\
\hline Дніпропетровська & 30641,6 & 19903,0 & 5850,0 & 4888,6 & 4 \\
\hline Донецька & 17119,4 & 10949,0 & 2015,0 & 4155,4 & 16 \\
\hline Житомирська & 11245,2 & 8301,0 & 975,0 & 1969,2 & 18 \\
\hline Закарпатська & 860,0 & 600,0 & 260,0 & 0,0 & 24 \\
\hline Запорізька & 28022,2 & 11046,0 & 3445,0 & 13531,2 & 8 \\
\hline Івано-Франківська & 5921,6 & 4119,0 & 585,0 & 1217,6 & 22 \\
\hline Київська & 29211,8 & 22529,0 & 2730,0 & 3952,8 & 6 \\
\hline Кіровоградська & 26515,8 & 15783,0 & 6500,0 & 4232,8 & 10 \\
\hline Луганська & 21035,4 & 6562,0 & 2665,0 & 11808,4 & 15 \\
\hline Львівська & 10014,4 & 6782,0 & 1950,0 & 1282,4 & 19 \\
\hline Миколаївська & 26052,1 & 11328,0 & 3965,0 & 10759,1 & 11 \\
\hline Одеська & 33655,1 & 13166,0 & 5395,0 & 15094,1 & 2 \\
\hline
\end{tabular}


Економічні науки". - Серія "Облік і фінанси". - Випуск 15 (57). - 2018.

Продовження табл. 3

\begin{tabular}{|c|c|c|c|c|c|}
\hline 1 & 2 & 3 & 4 & 5 & 6 \\
\hline Полтавська & 32035,1 & 22997,0 & 3900,0 & 5138,1 & 3 \\
\hline Рівненська & 6943,9 & 4477,0 & 650,0 & 1816,9 & 21 \\
\hline Сумська & 21085,0 & 14454,0 & 2080,0 & 4551,0 & 14 \\
\hline Тернопільська & 15489,2 & 9435,0 & 1495,0 & 4559,2 & 17 \\
\hline Харківська & 27935,5 & 18493,0 & 3965,0 & 5477,5 & 9 \\
\hline Херсонська & 24316,6 & 11423,0 & 3185,0 & 9708,6 & 12 \\
\hline Хмельницька & 24284,1 & 16325,0 & 2600,0 & 5359,1 & 13 \\
\hline Черкаська & 30256,4 & 24779,0 & 2860,0 & 2617,4 & 5 \\
\hline Чернівецька & 3533,8 & 2428,0 & 585,0 & 520,8 & 23 \\
\hline Чернігівська & 28833,0 & 13959,0 & 1755,0 & 13119,0 & 7 \\
\hline Україна & 499056,3 & 300000,0 & 65000,0 & 134056,3 & \\
\hline
\end{tabular}

Примітка. Сформовано на основі даних джерел: [8-10]

Дані наведено без урахування тимчасово окупованої теритоpiї АР Крим, м. Севастополя.

Як бачимо з даних табл. 1-3, у 2015-2017 роках сільському господарству було надано фінансової підтримки на 540,6 млн. грн.; 330,8 млн. грн. та 499,1 млн. грн. відповідно, з яких:

- на підтримку заходів шляхом здешевлення кредитів - 55,5\% (2015 рік), 86,1\% (2016 рік), 60,1\% (2017 рік);

- на підтримку розвитку фермерських господарств - 4,7\% (2015 рік), 4,8\% (2016 рік), 13,0\% (2017 рік);

- на підтримку тваринництва - 39,8\% (2015 рік), 9,1\% (2016 рік), 26,9\% (2017 рік).

Ці кошти розподілялися між регіонами пропорційно обсягам продукції, виробленої сільськогосподарськими підприємствами, що здійснюють діяльність на їх території. При цьому, за наявності рівних умов пріоритет надавався тим регіонам, в яких підприємства $є$ членами сільськогосподарського обслуговуючого кооперативу; займаються вирощуванням та розведенням великої рогатої худоби; обробляють земельні ділянки площею не більше ніж 500 гектарів; закладають молоді плодово-ягідні та виноградні насадження; переходять на виробництво органічної продукції.

Варто відмітити, що у 2017 році у порівнянні з 2016 роком державне фінансування шляхом здешевлення кредитів зменшилося на $16,0 \%$, проте збільшилося на підтримку розвитку фермерських господарств $(8,2 \%)$ та тваринництва $(17,8 \%)$. 
Аналіз державної фінансової підтримки в цілому в розрізі регіонів України показує, що у 2015 році найбільші обсяги фінансування отримували Полтавська та Чернігівська області, у 2016 році - Вінницька і Київська області, а у 2017 році - Вінницька, Одеська, Полтавська, Дніпропетровська і Черкаська області. На нашу думку, така ситуація пояснюється діяльністю в цих регіонах значної кількості сільськогосподарських підприємств, в тому числі і фермерських господарств, та значними обсягами виробництва ними продукції сільського господарства.

Щодо незначної державної фінансової підтримки, то така ситуація була характерна для Закарпатської (період 2015-2017 років). Тут варто зазначити, що найнижчий обсяг валової продукції сільського господарства був характерним саме Закарпатської області. Вважаємо, така ситуація, перш за все, пов'язана $з$ природними умовами Закарпаття, що не дозволяє забезпечувати достатній рівень рентабельності сільського господарства.

Загалом, зосередження значної частки бюджетних коштів лише у кількох регіонах вимагає здійснення коригування порядку розподілу ресурсів з урахуванням пріоритетів та перспектив регіонального розвитку, специфіки земельних площ, рентабельності сільськогосподарських підприємств в регіонах та інших факторів.

Крім державної підтримки, основним джерелом забезпечення коштами поточної діяльності сільськогосподарських підприємств залишається банківське кредитування.

За даними НБУ, обсяги кредитних ресурсів, наданих депозитними корпораціями (крім НБУ) сільськогосподарським підприємствам за період 2015-2017 років, зріс з 48425 млн. грн. до 59706 млн. грн., тобто на 23,3\% (табл. 4).

Проаналізуємо детальніше закономірності регіонального розподілу кредитів, наданих в сільське господарство (табл. 4).

Дані наведено без урахування тимчасово окупованої теритоpiї АР Крим, м. Севастополя

Дані свідчать, що обсяг кредитів для сільськогосподарських підприємств, не перевищував середнього значення по Україні в 2015 році у 18 регіонах України (2017,8 млн. грн.), в 2016 році - в 20 регіонах України (2307,3 млн. грн.), а в 2017 році - в 21 регіоні України (2487,8 млн. грн.). 
Економічні науки". - Серія "Облік і фінанси". - Випуск 15 (57). - 2018.

Таблиця 4

Рейтинг регіонів за обсягом кредитів, наданих депозитними корпораціями (крім НБУ) сільськогосподарським підприємствам,

у розрізі регіонів за період 2015-2017 років, млн. грн.

\begin{tabular}{|c|c|c|c|c|c|c|}
\hline Регіон & 2015 рік & Рейтинг & 2016 рік & Рейтинг & 2017 рік & Рейтинг \\
\hline Вінницька & 815 & 10 & 719 & 13 & 903 & 14 \\
\hline Волинська & 345 & 15 & 436 & 17 & 673 & 16 \\
\hline Дніпропетровська & 4223 & 2 & 6256 & 2 & 6971 & 2 \\
\hline Донецька & 336 & 17 & 294 & 20 & 100 & 24 \\
\hline Житомирська & 103 & 22 & 149 & 22 & 359 & 19 \\
\hline Закарпатська & 73 & $23 / 24$ & 73 & 24 & 118 & 22 \\
\hline Запорізька & 635 & 11 & 1063 & 11 & 1597 & 6 \\
\hline Івано-Франківська & 224 & 20 & 272 & 21 & 202 & 20 \\
\hline Київська & 26178 & 1 & 27532 & 1 & 30063 & 1 \\
\hline Кіровоградська & 594 & 13 & 1114 & 9 & 1372 & 8 \\
\hline Луганська & 73 & $23 / 24$ & 94 & 23 & 114 & 23 \\
\hline Львівська & 2439 & 3 & 2864 & 4 & 1468 & 7 \\
\hline Миколаївська & 2103 & 4 & 2253 & 5 & 1028 & 12 \\
\hline Одеська & 2074 & 6 & 1708 & 7 & 2240 & 4 \\
\hline Полтавська & 2075 & 5 & 1783 & 6 & 1692 & 5 \\
\hline Рівненська & 340 & 16 & 392 & 18 & 429 & 18 \\
\hline Сумська & 330 & 18 & 652 & 14 & 1017 & 13 \\
\hline Тернопільська & 627 & 12 & 1080 & 10 & 1166 & 10 \\
\hline Харківська & 1911 & 7 & 2944 & 3 & 4019 & 3 \\
\hline Херсонська & 405 & 14 & 551 & 16 & 670 & 17 \\
\hline Хмельницька & 1257 & 8 & 1285 & 8 & 1145 & 11 \\
\hline Черкаська & 870 & 9 & 947 & 12 & 1305 & 9 \\
\hline Чернівецька & 163 & 21 & 298 & 19 & 185 & 21 \\
\hline Чернігівська & 233 & 19 & 616 & 15 & 870 & 15 \\
\hline Україна & 48426 & - & 55375 & - & 59706 & - \\
\hline ПІримака Сса & \\
\hline
\end{tabular}

Примітка. Сформовано на основі даних джерела: [11]

Всього регіонами України було залучено кредитних коштів у 2015 році на суму 48,4 млрд. грн.; у 2016 році - на суму 55,4 млрд. грн.; у 2017 році - на суму 59,7 млрд. грн.. Отже, за аналізований період обсяг залучення кредитів в сільське господарство зріс на 23,3\%, що свідчить про відновлення довіри між банками та аграрним сектором.

У період 2015-2017 років найбільші обсяги кредитних ресурсів в Україні залучали сільськогосподарські підприємства Київської 
області, а найменші - Луганська (2015 рік), Закарпатська (2015-2016 роки) та Донецька (2017 рік) області.

Вважаємо, причинами низької активності щодо залучення кредитних ресурсів в сільське господарство багатьох регіонів протягом останніх років $є$ високі відсоткові ставки на кредитами; нестабільний фінансовий стан сільськогосподарських підприємств; високо ризикованість даного виду економічної діяльності.

3 метою формування стратегій щодо фінансування подальшого розвитку сільського господарства в регіонах України вважаємо за необхідне здійснити групування регіонів за рівнем фінансової підтримки сільського господарства (табл. 5 , рис. 1).

Таблиця 5

Інтегральний індекс регіонів за рівнем

фінансової підтримки сільського господарства (2017 рік)

\begin{tabular}{|c|c|c|c|c|c|}
\hline \multirow[b]{2}{*}{ Регіони } & \multicolumn{4}{|c|}{ Нормування показника } & \multirow[b]{2}{*}{ 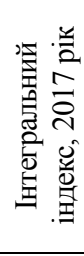 } \\
\hline & $\begin{array}{c}\text { Фінансова } \\
\text { підтримка } \\
\text { заходів } \\
\text { шляхом } \\
\text { здешевлення } \\
\text { кредитів }\end{array}$ & $\begin{array}{c}\text { Фінансова } \\
\text { підтримка } \\
\text { розвитку } \\
\text { фермерських } \\
\text { господарств }\end{array}$ & $\begin{array}{c}\text { Фінансова } \\
\text { підтримка } \\
\text { сільгосп- } \\
\text { товаро- } \\
\text { виробників }\end{array}$ & $\begin{array}{c}\text { Кредитне } \\
\text { забезпечення }\end{array}$ & \\
\hline 1 & 2 & 3 & 4 & 5 & 6 \\
\hline Вінницька & 1,000 & 0,700 & 0,460 & 0,030 & 0,547 \\
\hline Волинська & 0,201 & 0,160 & 0,090 & 0,022 & 0,118 \\
\hline Дніпропетровська & 0,792 & 0,900 & 0,324 & 0,232 & 0,562 \\
\hline Донецька & 0,436 & 0,310 & 0,275 & 0,003 & 0,256 \\
\hline Житомирська & 0,330 & 0,150 & 0,130 & 0,012 & 0,156 \\
\hline Закарпатська & 0,024 & 0,040 & 0,000 & 0,004 & 0,017 \\
\hline Запорізька & 0,440 & 0,530 & 0,896 & 0,053 & 0,480 \\
\hline Івано-Франківська & 0,164 & 0,090 & 0,081 & 0,007 & 0,085 \\
\hline Київська & 0,897 & 0,420 & 0,262 & 1,000 & 0,645 \\
\hline Кіровоградська & 0,628 & 1,000 & 0,280 & 0,046 & 0,489 \\
\hline Луганська & 0,261 & 0,410 & 0,782 & 0,004 & 0,364 \\
\hline Львівська & 0,270 & 0,300 & 0,085 & 0,049 & 0,176 \\
\hline Миколаївська & 0,451 & 0,610 & 0,713 & 0,034 & 0,452 \\
\hline Одеська & 0,524 & 0,830 & 1,000 & 0,075 & 0,607 \\
\hline Полтавська & 0,916 & 0,600 & 0,340 & 0,056 & 0,478 \\
\hline Рівненська & 0,178 & 0,100 & 0,120 & 0,014 & 0,103 \\
\hline Сумська & 0,575 & 0,320 & 0,302 & 0,034 & 0,308 \\
\hline Тернопільська & 0,376 & 0,230 & 0,302 & 0,039 & 0,237 \\
\hline Харківська & 0,736 & 0,610 & 0,363 & 0,134 & 0,461 \\
\hline
\end{tabular}


Економічні науки". - Серія "Облік і фінанси". - Випуск 15 (57). - 2018.

Продовження табл. 5

\begin{tabular}{|c|c|c|c|c|c|}
\hline 1 & 2 & 3 & 4 & 5 & 6 \\
\hline Херсонська & 0,455 & 0,490 & 0,643 & 0,022 & 0,403 \\
\hline Хмельницька & 0,650 & 0,400 & 0,355 & 0,038 & 0,361 \\
\hline Черкаська & 0,987 & 0,440 & 0,173 & 0,043 & 0,411 \\
\hline Чернівецька & 0,097 & 0,090 & 0,035 & 0,006 & 0,057 \\
\hline Чернігівська & 0,556 & 0,270 & 0,869 & 0,029 & 0,431 \\
\hline
\end{tabular}

Примітка. Сформовано авторами

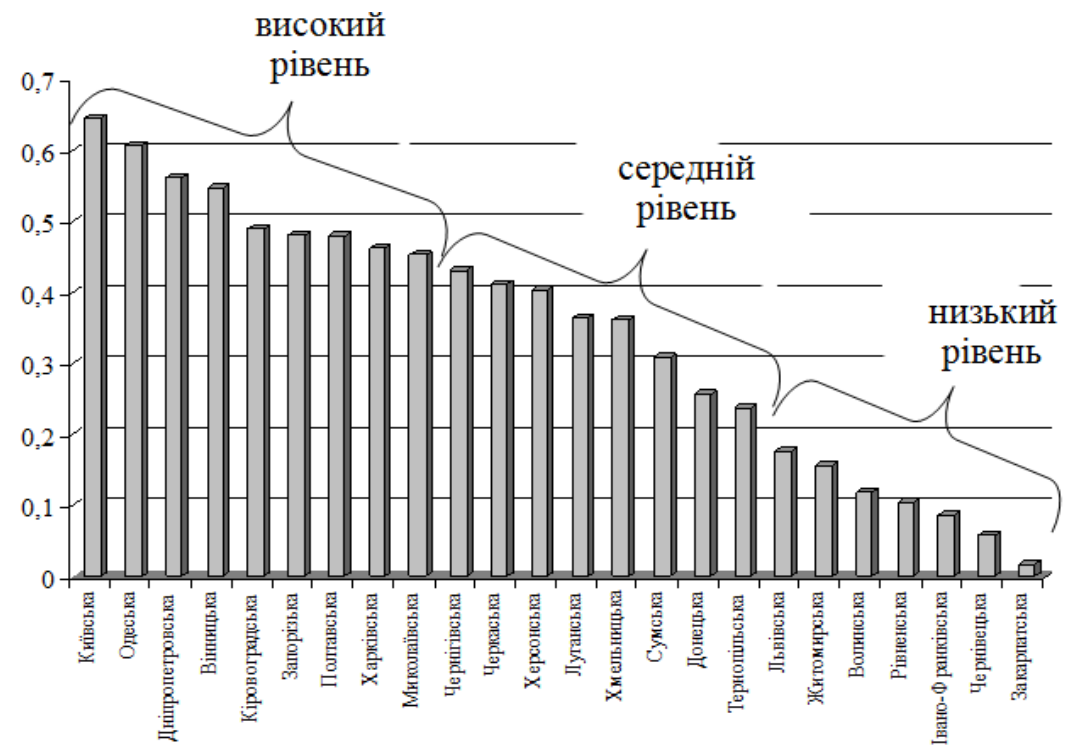

Рис. 1. Групування регіонів за рівнем фінансової підтримки сільського господарства (2017 рік)

Примітка. Сформовано авторами

Отже, високий рівень фінансової підтримки сільського господарства характерний 9-ти регіонам (Київська, Одеська, Дніпропетровська, Вінницька, Кіровоградська, Запорізька, Полтавська, Харківська та Миколаївська області); середній рівень - 8-и регіонам (Чернігівська, Черкаська, Херсонська, Луганська, Хмельницька, Сумська, Донецька і Тернопільська області); низький рівень - решті 7-и регіонам 
(Львівська, Житомирська, Волинська, Рівненська, Івано-Франківська, Чернівецька і Закарпатська області).

Проаналізувавши групування регіонів за рівнем фінансування, можемо зробити висновок, що за обсягами сільськогосподарського виробництва Вінницька (20,4 млрд. грн.), Дніпропетровська (15,3 млрд. грн.), Київська (14,9 млрд. грн.), Полтавська (14,3 млрд. грн.) та Харківська (11,1 млрд. грн.) області дійсно заслуговують на підтримку з боку держави та банків. Проте, деякі регіони, випереджаючи інші регіони за обсягом сільськогосподарського виробництва, на нашу думку, не доотримували необхідного фінансування. Так, за обсягом сільськогосподарського виробництва Хмельницька (14,1 млрд. грн.) та Черкаська (13,3 млрд. грн.) області у 2017 році випереджали Одеську область (11,8 млрд. грн.); Херсонська (11,2 млрд. грн.) та Чернігівська (10,9 млрд. грн.) області - Кіровоградську область (10,4 млрд. грн.); Сумська (10,2 млрд. грн.), Житомирська (9,9 млрд. грн.), Львівська (9,8 млрд. грн.) області - Запорізьку область (9,6 млрд. грн.); Тернопільська область (9,5 млрд. грн.) - Миколаївську (8,8 млрд. грн.).

Висновки. Для покращення ситуації щодо фінансової підтримки сільського господарства необхідно: 1) спрямовувати кошти бюджетної підтримки сільського господарства у регіони, що забезпечують значні обсяги сільського господарського виробництва; 2) вдосконалити існуючий підхід щодо підтримки фермерських господарств у регіонах; 3) покращити умови доступу та спростити адміністрування програм фінансової підтримки для сільськогосподарських підприємств; 4) здійснювати контроль за розподілом державних ресурсів в розрізі регіонів на етапі реалізації програм; 5) банкам утриматися від необгрунтованого підвищення відсоткових ставок за кредитами; 6) надати рівні умови кредитування великим, середнім та малим сільськогосподарських підприємствам і фермерським господарствам усіх регіонів.

1. Статистичний збірник «Сільське господарство України» за 2017 рік. - Київ : Державна служба статистики України, 2018. - 245 с.

2. Розподіл бюджетних призначень, передбачених у державному бюджеті на 2015 рік для фінансової підтримки заходів в агропромисловому комплексі шляхом здешевлення кредитів (КПКВК 2801030 «Фінансова підтримка заходів в агропромисловому комплексі шляхом здешевлення кредитів» // Наказ Міністерства аграрної політики та продовольства України від 04.06.2015 р. №210. 
3. Розподіл коштів, передбачених в державному бюджеті на 2015 рік на фінансову підтримку фермерських господарств на поворотній основі (КПКВ 2801460 «Надання кредитів фермерським господарствам») // Наказ Міністерства аграрної політики та продовольства України від 02.03.2015 р. №70.

4. Розподіл річних лімітів для виплати часткового відшкодування вартості будівництва та реконструкції тваринницьких ферм і комплексів, доїльних залів та утворених на кооперативних засадах м'ясопереробних підприємств // Наказ Міністерства аграрної політики та продовольства України від 02.12.2015 р. №463.

5. Розподіл бюджетних призначень, передбачених у державному бюджеті на 2016 рік для фінансової підтримки заходів в агропромисловому комплексі шляхом здешевлення кредитів (КПКВК 2801030 «Фінансова підтримка заходів в агропромисловому комплексі шляхом здешевлення кредитів» // Наказ Міністерства аграрної політики та продовольства України від 09.12.2016 р. №534.

6. Розподіл коштів, передбачених в державному бюджеті на 2016 рік на фінансову підтримку фермерських господарств на поворотній основі (КПКВ 2801460 «Надання кредитів фермерським господарствам») // Наказ Міністерства аграрної політики та продовольства України від 01.03.2016 р. №69.

7. Розподіл бюджетних коштів, передбачених за КПКВК 2801540 «Державна підтримка галузі тваринництва» для виплати часткового відшкодування вартості закуплених для подальшого відтворення телиць, нетелей, корів вітчизняного походження та племінних телиць, нетелей, корів молочного, молочно-м'ясного і м'ясного напряму продуктивності, племінних свинок та кнурців (класу «еліта»), племінних вівцематок, баранів, ярок // Наказ Міністерства аграрної політики та продовольства України від 30.11.2016 р. №498.

8. Розподіл бюджетних призначень, передбачених у державному бюджеті на 2017 рік для фінансової підтримки заходів в агропромисловому комплексі шляхом здешевлення кредитів (КПКВК 2801030 «Фінансова підтримка заходів в агропромисловому комплексі шляхом здешевлення кредитів» // Наказ Міністерства аграрної політики та продовольства України від 28.07.2017 р. №388.

9. Розподіл коштів, передбачених у державному бюджеті на 2017 рік для надання фінансової підтримки фермерським господарствам на поворотній основі (КПКВК 2801460 «Надання кредитів фермерським господарствам») // Наказ Міністерства аграрної політики та продовольства України від 14.02.2017 p. №65.

10. Фінансування програми часткової компенсації за сільськогосподарську техніку та обладнання вітчизняного виробництва сільгосптоваровиробників у 2017 році // Сайт Міністерства аграрної політики та продовольства України / Підтримка аграріїв // [Електронний ресурс]. - Режим доступу : http://minagro.gov.ua/uk/support_ apk?nid=24340.

11. Сайт Національного банку України / Грошово-кредитна фінансова статистика // [Електронний ресурс]. - Режим доступу : https://bank.gov.ua/control/uk/ publish/article?art_id=27843415\&cat_id=44578\#1. 